\title{
Ameliorative Effect of Propolis Against Thioacetamide Induced Hepatorenal Injury in Adult Male Rats. Kidney Injury Molecule-1 (KIM-1) a Biomarker of Renal Injury
}

\author{
RANIA S.A.E. MANSOUR, M.D.*; SAMAR F. EZZAT, M.D.** and DOAA A. ABOU-BAKR, M.D.* \\ The Departments of Physiology* and Histology \& Cell Biology**, Faculty of Medicine, Ain Shams University
}

\begin{abstract}
Background: Thioacetamide (TAA), a known industrial toxic agent, is extensively used in animal studies for induction of hepatic necrosis, fibrosis and cirrhosis, also reported to be nephrotoxic through induction of oxidative stress. Propolis, bee glue, is known by its antioxidant and anti-inflammatory properties.
\end{abstract}

Aim of Study: This work aimed to evaluate the potential protective effect of propolis on TAA-induced hepatorenal damage and to evaluate the efficacy of Kidney Injury Molecuole-1 (KIM-1) in early detection of renal injury.

Material and Methods: This study was performed on 24 adult male albino rats, divided into 3 groups; (I) Control group, (II) TAA-group (TAA was given in a dose of $50 \mathrm{mg} / \mathrm{kg}$ /day intraperitoneally, 5 days/week for 2 weeks), (III) TAApropolis treated group (TAA was given in the same way as in TAA-group, propolis was given in a dose of $500 \mathrm{mg} / \mathrm{kg} / \mathrm{day}$ by gavage, 5 days/week for 2 weeks). All studied rats were subjected to determination of initial and final body weight, body weight percent change, absolute and relative liver and kidney weight, as well as assessment of hepatic function by serum Alanine Transaminase (ALT) and Aspartate Transaminase (AST), renal function by serum urea, creatinine and potassium $(\mathrm{K}+)$ level, with determination of renal tissue oxidative stress markers; Malondialdehyde (MDA) and Glutathione-S-Transferase (GST), inflammatory marker; Myeloperoxidase (MPO), renal tissue damage marker; Kidney Injury Molecule-1 (KIM-1). In addition, specimens of liver and kidney were taken and processed for light microscopic studies.

Results: TAA induced hepatotoxic and nephrotoxic effect that was evident by the significantly increased serum ALT, AST, urea and creatinine, with significant decrease in serum $\mathrm{K}^{+}$level as well as significantly increased renal tissue MDA, GST, MPO and KIM-1 when compared with control group. Treatment with propolis caused significant reduction in serum ALT, AST, urea and creatinine, with significant elevation in serum $\mathrm{K}^{+}$as well as significant reduction in renal tissue MDA, GST, MPO and KIM-1 when compared to the TAA group, but still significantly higher compared to controls except for

Correspondence to: Dr. Doaa Ahmed Abou-Bakr, E-Mail: doaaabou-bakr@med.asu.edu.eg doaa1510@gmail.com urea. These results were confirmed by the histopathological findings.

Conclusion: Propolis could partially ameliorate the TAA induced hepatorenal damage, which might be related to attenuation of oxidative stress and inflammation. Moreover, KIM-1 could be beneficial in detection of renal injury.

Key Words: Hepatorenal injury - Thioacetamide - Propolis - Oxidative stress - Inflammation - KIM-1 Histopathology.

\section{Introduction}

THIOACETAMIDE (TAA) is a widely used sulfur containing compound in the laboratory and in various technical applications [1], as fungicides, rubber chemicals, curing agents, cross linking agents, metallurgy, pesticides and pharmaceuticals [2]

TAA was reported to be hepatotoxic and nephrotoxic [3], genotoxic and carcinogenic [4], widely used in experimental models of liver injury [5], and renal toxicity [6].

TAA toxicity is due to its rapid metabolism by cytochrome $\mathrm{P} 450$ and flavin-containing monooxygenases to reactive metabolites (thioacetamide-Soxide and reactive oxygen species; ROS) [7]

Oxidative Stress (OS) has long been implicated in the pathogenesis of liver and renal damage [8] The kidney is more vulnerable to damage by ROS than other organs due to the abundance of longchain-polyunsaturated fatty acids [9]. Therefore, great attention has been paid to antioxidants or free radical scavengers for the prevention and treatment of acute and chronic liver and kidney damages.

Propolis a gum like substance gathered by bees from various plants [10], possesses a broad spectrum 
of biological activities such as anti-hepatitis and anti-arthritis [11,12], antimicrobial, anti-allergic, dermato-protective, laxative, anti-diabetic, immunomodulatory, antitumor, and antibiotic activities [13]. These biological activities may be attributed to its constituents obtained from plants, mainly phenolic compounds such as flavonoids, at least 38 different flavonoids have been reported in propolis [14]. Flavonoids are well-known antioxidant possessing free radical scavenging and metal chelating activity [15]

Kidney Injury Molecule-1 (KIM-1) is a new biomarker of kidney injury that could be detected even before blood urea and creatinine elevation in early stages of renal injury, besides being more specific to renal tissue [16].

The present study therefore aimed to evaluate the potential ameliorative effect of propolis against hepatorenal injury induced by TAA.

\section{Material and Methods}

\section{Chemicals:}

Thioacetamide (TAA) was purchased from Sigma-Aldrich Corp., St. Louis, MO, USA. Bee Propolis (100\% natural dried extract powder) was purchased from Imtenan Health Shop, Cairo, Egypt.

\section{Animals:}

The present study was performed in May 2019, on 24 adult male albino rats weighing 200-270 grams at the start of the study. Rats were purchased from VACSERA HELWAN and were kept in the Medical Ain Shams Research Institute (MASRI) in animal cages (4/cage) with suitable ventilation and temperature of $22-25^{\circ} \mathrm{C}$. Rats were left for 7 days as a period of acclimatization. Regular meals were introduced daily, with free access to water and food. Animals were not exposed to unnecessary pain or stress and manipulated with maximal care and hygiene.

\section{Experimental procedure:}

Rats were allocated into 3 groups; Group I (Control, $n=8$ ): Rats in this group received distilled water by gavage and intraperitoneal injection of normal saline ( $\mathrm{NaCl} 0.9 \%), 5$ days/week for 2 weeks. Group II (Thioacetamide (TAA) group, $\mathrm{n}=8$ ); rats received TAA dissolved in $\mathrm{NaCl} 0.9 \%$ given intraperitoneally in a dose of $50 \mathrm{mg} / \mathrm{kg} /$ day, 5 days/week for 2 weeks, this dose and duration causes low grade injury as described by Murad et al., [17] . Group III (TAA-propolis treated group, $\mathrm{n}=8$ ); rats in this group received TAA as in group 2 and propolis that was dissolved in distilled water, then given by gavage in a dose of $500 \mathrm{mg} / \mathrm{kg} / \mathrm{day}$, 5 days/week for 2 weeks [18]

At the end of the study, overnight fasted rats were weighed anaesthetized by pentobarbital in a dose of $40 \mathrm{mg} / \mathrm{kg}$ body weight. Blood samples were collected and centrifuged at 3000rpm for 15 minutes to separate serum. The separated serum was then pipetted into clean storage eppendorf and stored at $-20^{\circ} \mathrm{C}$ for later determination of Alanine Transaminase (ALT), Aspartate Transaminase (AST), urea, creatinine and potassium $(\mathrm{K}+)$. Then kidneys and liver were excised, washed by normal saline, weighed and the right one was stored at $-20^{\circ} \mathrm{C}$ for later determination of renal tissue Malondialdehyde (MDA), Glutathione-STransferase (GST), Myeloperoxidase (MPO) and Kidney Injury Molecule-1 (KIM-1). Both liver and left kidney underwent histological studies.

Determination of liver enzymes as markers of hepatic injury: Both ALT and AST were quantitatively assessed by colorimetric method as described by Tietz [19] using Biomed diagnostics kits, Egypt.

Estimation of kidney function by serum urea, creatinine and potassium: Serum urea and creatinine were quantitatively assessed colorimetrically as described by Vassault et al., [20] \& Young et al., [21] respectively, using Biomed diagnostics kits, Egypt. Serum potassium was flourometrically assayed using BioVision kit, USA according to manufacture instructions.

Determination of renal tissue Malondialdehyde (MDA) and Glutathione-S-Transferase (GST) as oxidative stress markers: Both MDA and GST were estimated colorimetrically as described by Ohkawa et al., [22] \& Habig et al., [23], respectively using biodiagnostic kits, Egypt.

Assessment of renal tissue Myeloperoxidase $(M P O)$ as an inflammatory marker: MPO was assessed quantitatively using rat specific CLIA (Chemiluminescence Immunoassay) kit, LifeSpan BioSciences, USA, following manufacture instruction.

Determination of renal tissue damage by Kidney Injury Molecule- 1(KIM-1): KIM-1 was assessed using rat specific ELISA kit, CUSABIO, China, according to manufacture instructions.

\section{Histological studies:}

Liver and Kidney were collected then fixed immediately in $10 \%$ neutral buffered formalin solution for $24 \mathrm{~h}$, dehydrated in a graded ethanol series, and processed for paraffin embedding for 
light microscopic study. Serial sections (5thick) were prepared and stained with hematoxylin and eosin (H \& E), Periodic Acid Schiff (PAS) and Mallory's trichrome stain [24]. Sections were examined and photographed with Olympus BX 40 light microscope (Olympus, Hamburg, Germany) connected to a camera Canon power shot A640 digital camera (Canon Inc., Tokyo, Japan).

Morphometric analysis: Five specimens from five different rats of each group were examined $(n=5)$. For each specimen, five different captured non-overlapping high-power fields (X 200) were taken. Five different readings from every captured photo were counted and the mean was calculated for each specimen. Measurements were counted by an independent observer blinded to the specimens' details to perform an unbiased assessment. Samples were analyzed by using Leica DM2500 microscope with built in camera (Wetzlar, Germany). All images were digitally acquired using an image analyzer Leica Q win V.3 program (Wetzlar, Germany) installed on a computer in the Histology Department Faculty of Medicine Ain Shams University. The following parameters were measured:

A- Area\% for collagen fibers content.

B- Mean optical density of PAS stained glycogen content.

\section{Statistical analysis:}

All statistical data and statistical significance were performed using SPSS (statistical program for social science) statistical package (SPSS Inc.) version 20. Differences between groups were compared by one-way ANOVA with Least Significant Difference test (LSD). The association between the parameters was determined using the Pearson's correlation coefficient. $p<0.05$ was considered statistically significant.

\section{Results}

Mortality rate: Calculated mortality rate was $27.27 \%$ in the TAA group throughout the period of the study ( 3 out of 11), therefore, only 8 rats out of 11 were included in each studied group.

As shown in (Table 1) IBW, ALW and AKW were insignificantly changed among the 3 studied groups. However, both TAA group and TAAPropolis treated group showed significant reduction in FBW and BW\% with significant increase in RLW and RKW when compared with control rats, but no significant changes were detected between TAA group and TAA-Propolis treated group.

Table (2) shows significant increase in ALT, AST, urea and creatinine, with significant decrease in $\mathrm{K}+$ level in TAA group as compared with controls. TAA-Propolis treated group showed significant reduction in ALT, AST, urea and creatinine, with significant elevation in $\mathrm{K}^{+}$level when compared with TAA group, however, the values were still significantly different from the control group except for serum urea level which was insignificant from controls.

In (Table 3) TAA group shows significant increment in renal tissue MDA, GST, MPO and KIM1 when compared with control rats. While TAAPropolis treated group showed significant decrement in all parameters when compared with TAA group but still significantly elevated from control group.

Table (1): Mean \pm SEM values of initial body weight (IBW; gm), final body weight (FBW; gm), body weight percent change (BW\%; \%), absolute liver weight (ALW; gm), relative liver weight (RLW; \%), absolute kidney weight (AKW; gm) and relative kidney weight (RKW; \%) in all studied groups.

\begin{tabular}{|c|c|c|c|c|c|c|c|}
\hline Groups Parameters & IBW & FBW & BW\% & ALW & RLW & AKW & RKW \\
\hline Control & $259.00 \pm 12.19$ & $271.00 \pm 13.12$ & $4.59 \pm 0.61$ & $6.92 \pm 0.33$ & $2.56 \pm 0.01$ & $1.20 \pm 0.09$ & $0.44 \pm 0.01$ \\
\hline TAA & $260.11 \pm 5.00$ & $222.78 \pm 9.43 \mathbf{a}$ & $-14.47 \pm 3.04^{\mathbf{a}}$ & $7.72 \pm 0.42$ & $3.49 \pm 0.19 \mathbf{a}$ & $1.24 \pm 0.05$ & $0.57 \pm 0.03 \mathbf{a}$ \\
\hline TAA-Propolis treated & $243.00 \pm 2.98$ & $203.00 \pm 3.30 \mathbf{a}$ & $-16.19 \pm 1.06^{\mathbf{a}}$ & $7.52 \pm 0.24$ & $3.69 \pm 0.10 \mathrm{a}$ & $1.22 \pm 0.08$ & $0.60 \pm 0.03 \mathbf{a}$ \\
\hline
\end{tabular}

a: Significance by LSD from control group with $p \leq 0.05$.

Table (2): Mean \pm SEM values of serum alanine transaminase (ALT; U/l), aspartate transaminase (AST; $\mathrm{U} / \mathrm{l})$, urea (Urea; $\mathrm{mg} \%)$, creatinine (Creat.; $\mathrm{mg} \%)$ and potassium $\left(\mathrm{K}^{+} ; \mathrm{nmol} / \mathrm{ml}\right)$ in all studied groups.

\begin{tabular}{|c|c|c|c|c|c|}
\hline Groups $\quad$ Parameters & ALT & AST & Urea & Creat. & $\mathrm{K}+$ \\
\hline Control & $18.75 \pm 1.03$ & $13.88 \pm 0.69$ & $48.04 \pm 2.70$ & $0.18 \pm 0.03$ & $5.06 \pm 0.06$ \\
\hline TAA & $59.89 \pm 4.87 \mathbf{a}$ & $38.56 \pm 2.06 \mathbf{a}$ & $81.47 \pm 3.53 \mathbf{a}$ & $1.04 \pm 0.06 \mathbf{a}$ & $4.22 \pm 0.07 \mathbf{a}$ \\
\hline TAA-Propolis treated & $31.00 \pm 1.221 \mathbf{a b}$ & $24.25 \pm 1.44 \mathbf{a b}$ & $55.04 \pm 3.08 \mathbf{b}$ & $0.55 \pm 0.06^{\mathbf{a b}}$ & $4.76 \pm 0.12^{\mathbf{a b}}$ \\
\hline
\end{tabular}

a: Significance by LSD from control group with $p \leq 0.05 . \quad$ b: Significance by LSD from TAA group with $p \leq 0.05$. 
Table (3): Mean \pm SEM values of renal tissue malondialdehyde (MDA; nmol/gm), glutathione-Stransferase (GST; U/gm), myeloperoxidase (MPO; pg/gm) and Kidney injury molecule1 (KIM-1; ng/gm) in all studied groups.

\begin{tabular}{|c|c|c|c|c|}
\hline Groups $\quad$ Parameters & MDA & GST & MPO & KIM-1 \\
\hline Contr & $38.51 \pm$ & $114.45 \pm 1.41$ & $20.95 \pm 1.52$ & 79.03 \\
\hline TAA & $106.71 \pm 3.41 \mathbf{a}$ & $212.48 \pm 3.75 \mathbf{a}$ & $49.84 \pm 1.11 \mathrm{a}$ & $157.74 \pm 6.29$ \\
\hline TAA-Propolis treated & $66.69 \pm 2.84$ ab & $151.74 \pm 6.94$ ab & $27.50 \pm 2.22 \mathbf{a b}$ & $105.55 \pm 3.01 \mathbf{a b}$ \\
\hline
\end{tabular}

a: Significance by LSD from control group with $p \leq 0.05$.

b: Significance by LSD from TAA group with $p \leq 0.05$.

Correlation study: In Fig. (I), significant positive correlations were demonstrated between serum
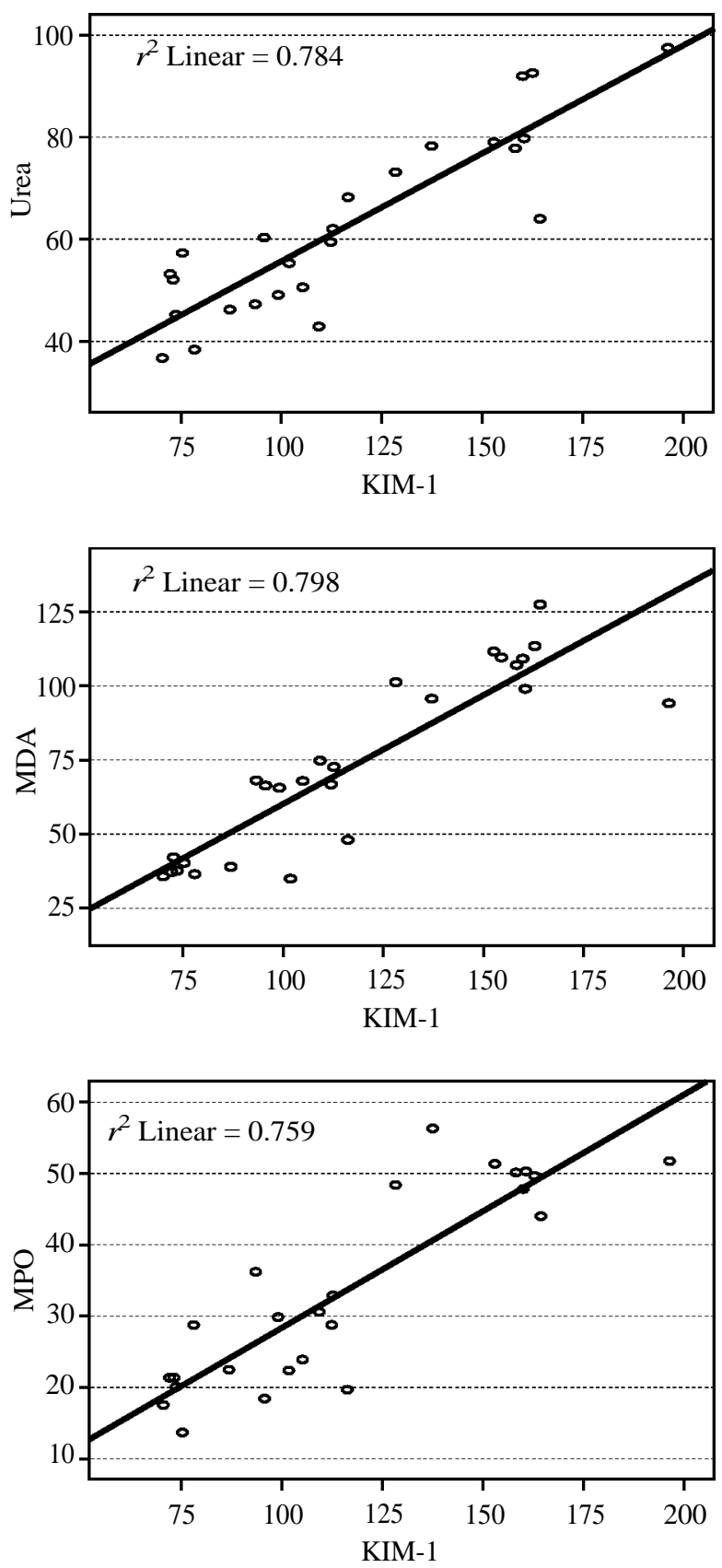

urea, creatinine and kidney tissue MDA, GST, MPO with kidney tissue KIM- 1 at $p<0.01$.
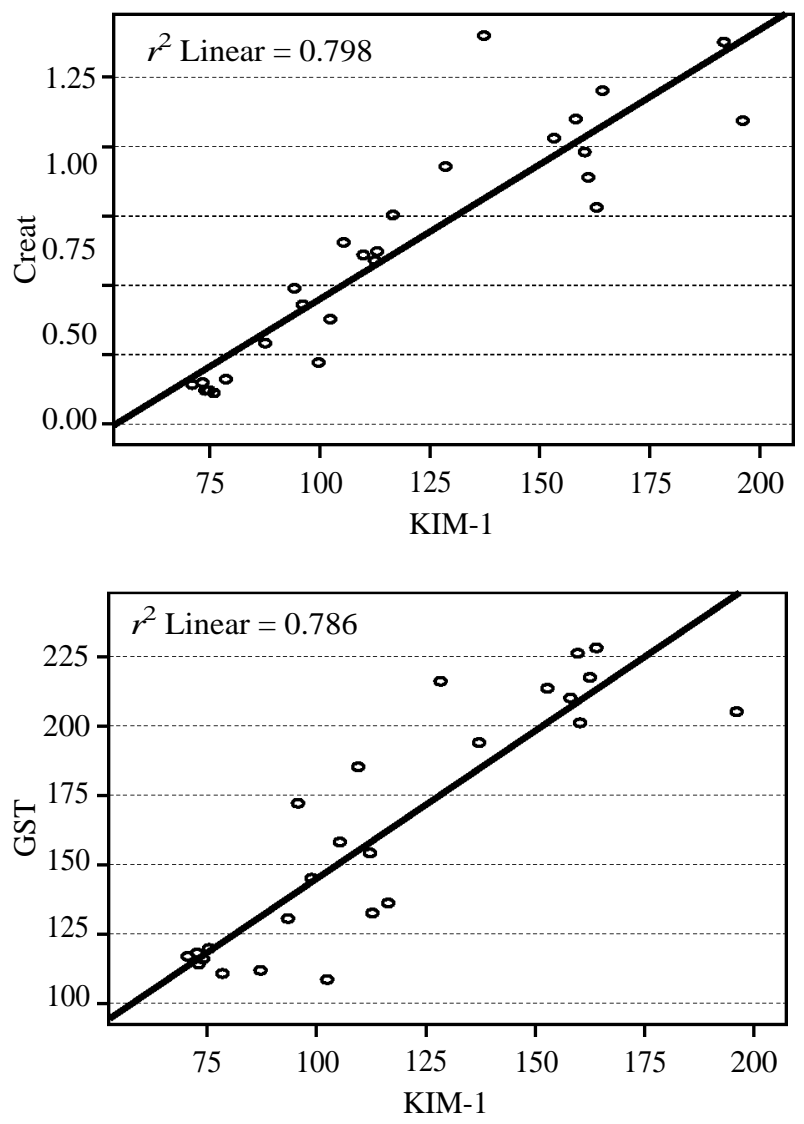

Fig. (I): Correlations between serum urea, creatinine and renal tissue MDA, GST, MPO with KIM-1 in all studied groups. 


\section{Histopathological results:}

Results of the liver:

Examination of $\mathrm{H} \& \mathrm{E}$ stained liver sections of rats of control group revealed normal liver parenchyma formed of branching and anastomosing cords of hepatocytes radiating from central veins. Hepatocytes appeared polygonal with acidophilic granular cytoplasm and central rounded vesicular nuclei. Some cells were binucleated. Blood sinusoids in between hepatocyte cords were lined by flat endothelial cells and kupffer cells Fig. (1A). Portal tract contained branches of portal vein, hepatic artery and bile ductules Fig. (1B).

Administration of TAA to rats in group II led to disruption of the radial arrangement of the hepatic cords. Most of hepatocytes had apparently large nuclei with prominent multiple nucleoli and margination of chromatin. The cytoplasm of these hepatocytes appeared deeply acidophilic Fig. (2A). While some other hepatocytes showed vacuolated cytoplasm and small dark nuclei that were shifted peripherally in some cells. Mononuclear cellular infiltration was seen in between hepatocytes Fig. (2B). Dilated congested blood sinusoids were also noticed Fig. (2A). Portal tracts appeared expanded with cellular infiltration. Portal veins were seen dilated and congested with interrupted vessel wall. Proliferation of bile ducts was evident Fig. (2C).

Propolis attenuated the hepatic injury induced by TAA in group III. Restoration of normal liver architecture was noticed. Few cells appeared with vacuolated cytoplasm and small dark nuclei while the rest of the hepatocytes appeared with acidophilic cytoplasm and vesicular nuclei. Some dilated blood sinusoids could be noticed Fig. (3A). Portal tracts were less expanded with minimal cellular infiltration Fig. (3B).

On examination of Mallory's trichrome stained liver sections of the control group, few blue collagen fibers were seen around the central vein Fig. (4A), at the portal tracts and between hepatocytes Fig. (4B). In TAA group, the collagen fiber content was significantly increased $(p<0.05)$ (Table 2$)$ around the central vein and between hepatocytes Fig. (4C) and in the portal tracts Fig. (4D) as compared to the control group. Administration of propolis with TAA in group III led to significant decrease $(p<0.05)$ (Table 2$)$ in collagen fiber content around central vein Fig. (4E) and in the portal tracts Fig. (4F) in comparison to group II.

PAS stained sections revealed that most of the hepatocytes of group I had PAS positive granules in their cytoplasm Fig. (5A). In group II, the PAS positive glycogen granules were significantly decreased $(p<0.05)$ (Table 2$)$ as compared to that of the control group Fig. (5B). In group III significant increase $(p<0.05)$ (Table 2) in PAS positive granules was noticed in the hepatocytes cytoplasm as compared to group II Fig. (5C).

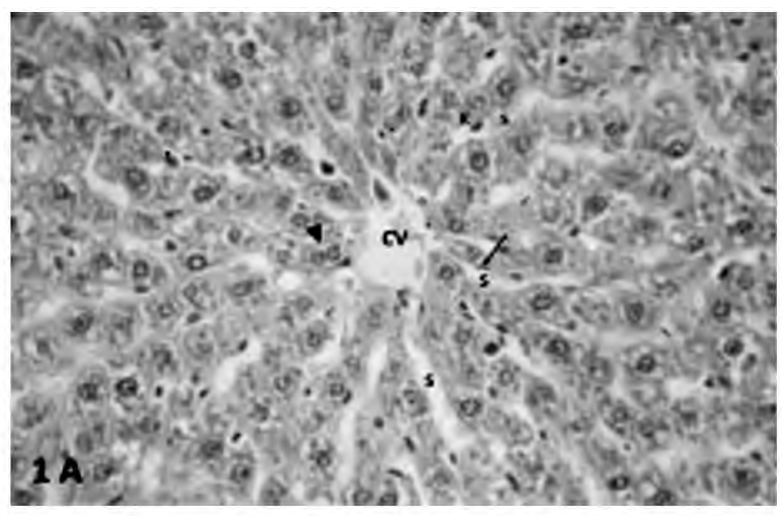

(A)

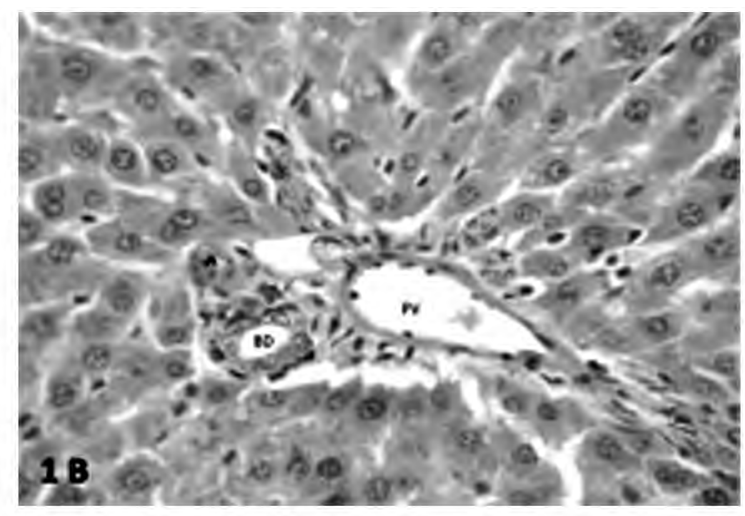

(B)

Fig. (1): (A) A photomicrograph of section of rat liver showing Central Vein (CV) and radiating plates of hepatocytes. Cells are polygonal with acidophilic granular cytoplasm and central rounded vesicular nuclei. Some cells are binucleated (A). Blood sinusoids (S) in between hepatocyte cords are lined by flat endothelial cells $(\uparrow)$ and kupffer cells (K). (B) Showing portal tract containing branches of Portal Vein (PV), hepatic artery (A) and Bile Duct (BD). Group I, H \& E stain, X400. 


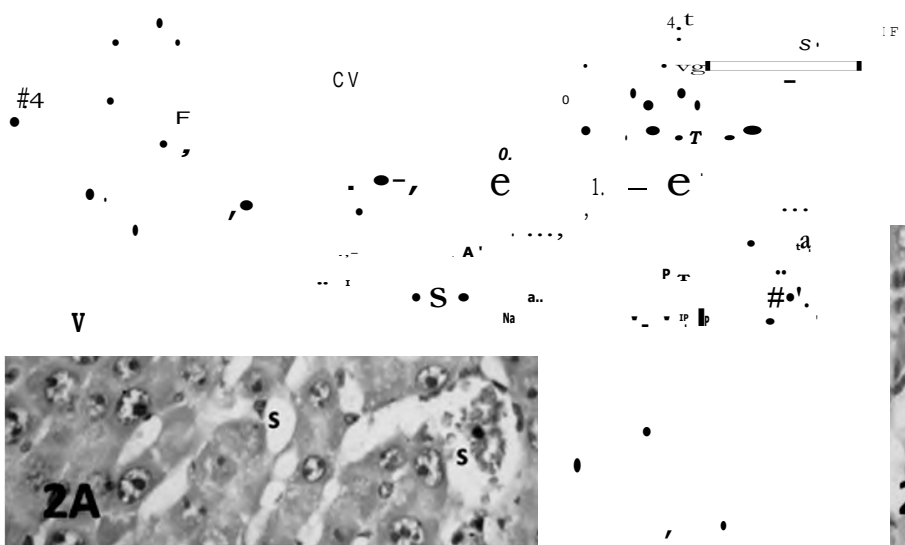

(A)

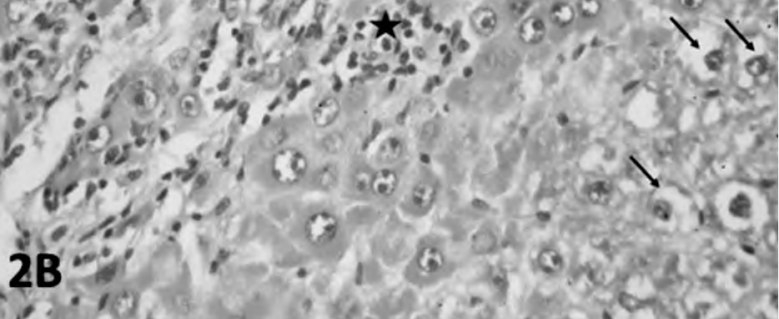

(B)

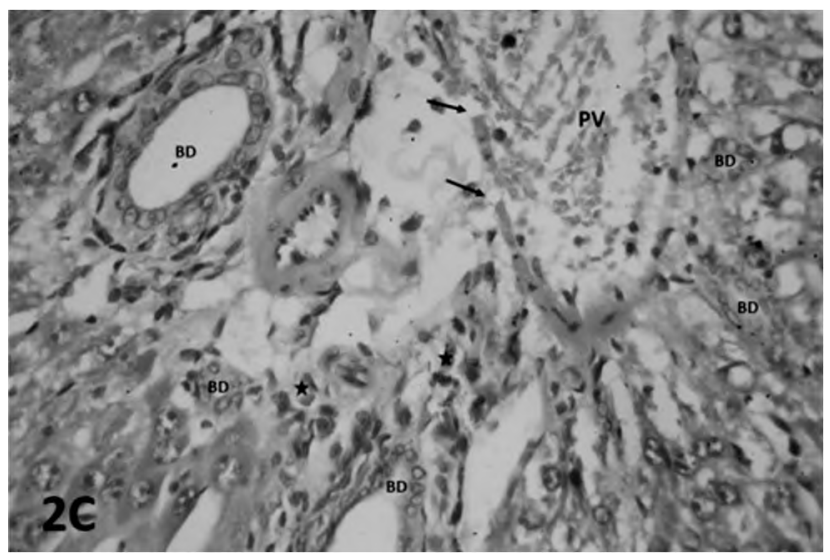

(C)

Fig. (2): (A) Showing disruption of the radial arrangement of the hepatic cords. Dilated central vein is seen (CV). Most of hepatocytes have apparently large nuclei with prominent multiple nucleoli and margination of chromatin (A). The cytoplasm of these hepatocytes is deeply acidophilic. Dilated congested blood sinusoids are also noticed (S). (B) Showing mononuclear cellular infiltration in between hepatocytes $(*)$. Some hepatocytes are seen with vacuolated cytoplasm and small dark peripheral nuclei (?), (C) Showing expanded portal tract with cellular infiltration $(*)$. Portal vein appears dilated and congested (PV) with interrupted vessel wall (?). Proliferation of bile ducts is also evident (BD). Group II. H \& E stain, X400.

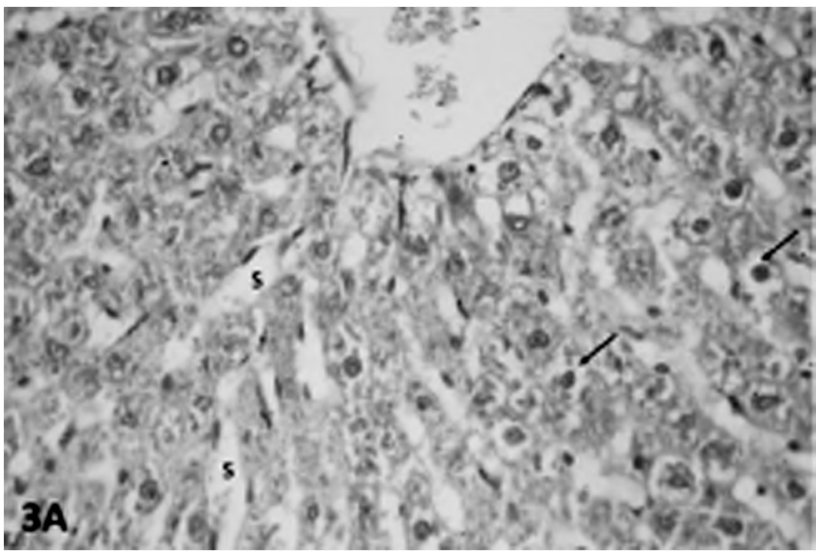

(A)

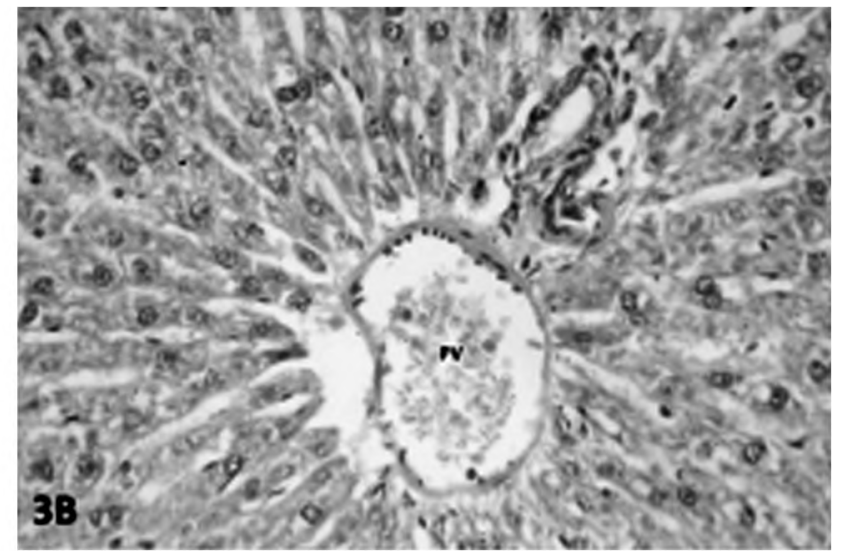

(B)

Fig. (3): (A) Showing radially arranged hepatic cords separated by blood sinusoids, some of them are still dilated (S). Most of hepatocytes appear with acidophilic cytoplasm and central rounded vesicular nuclei, while some few cells are seen with vacuolated cytoplasm and dark nuclei (?). (B) Showing less expanded portal tract with apparent decrease in cellular infiltration as compared to group II. Congested portal vein is seen (PV). Group III. H \& E stain, X400. 

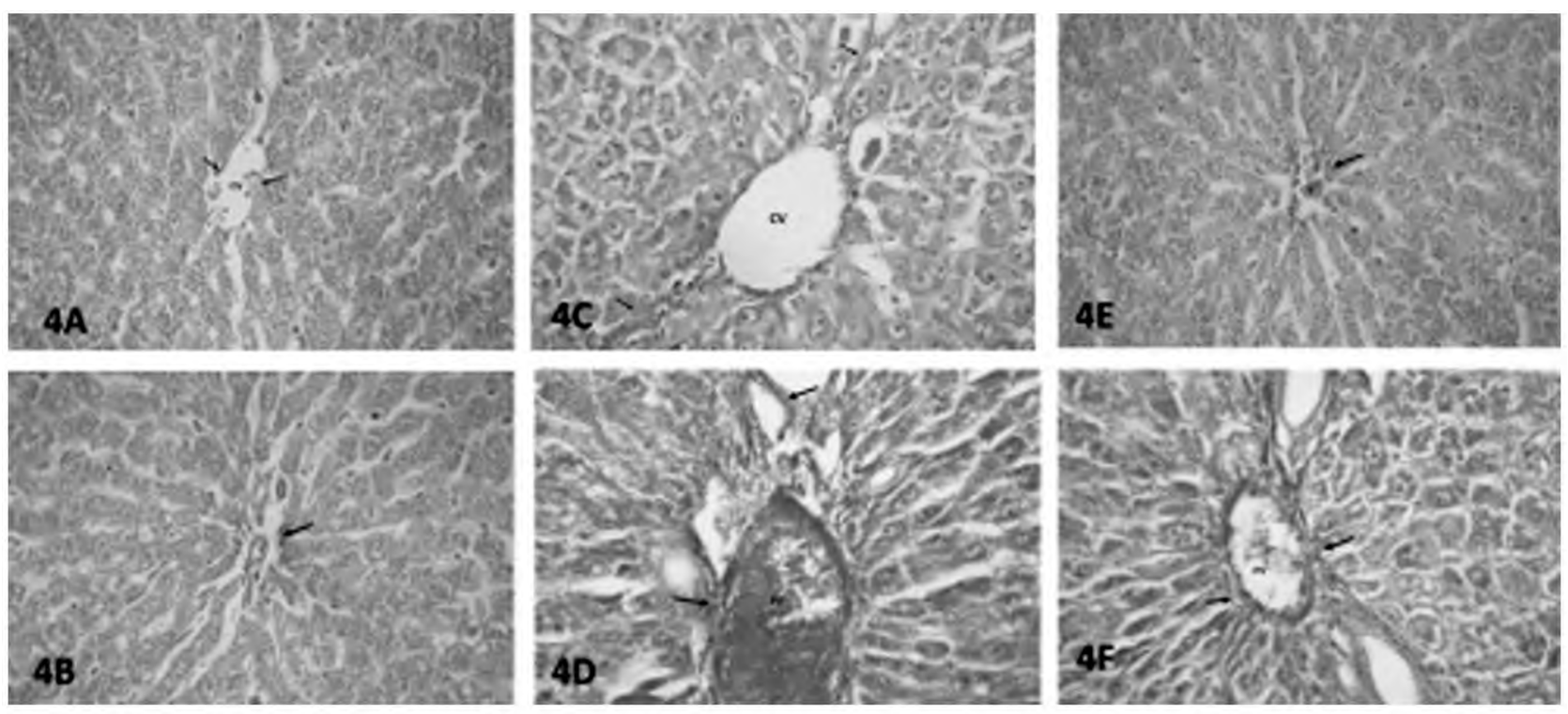

Fig. (4): (A \& B) Control group (A) Showing few blue collagen fibers around the central vein ( $\uparrow$ ). (B) Showing few blue collagen fibers at the portal tract $(\uparrow)$ and between hepatocytes. (C \& D) Group II: (C) Showing apparent increase in the collagen fibers around the central vein and between hepatocytes ( $\uparrow$ ) (D) Showing increase collagen fibers in the portal tract ( $\uparrow)$. (E \& F) Group III: (E) Showing apparent decrease in collagen fiber content around central vein $(\uparrow)$ (F) showing apparent decrease in collagen fibers in the portal tract $(\uparrow)$. Mallory's trichrome stain X400.
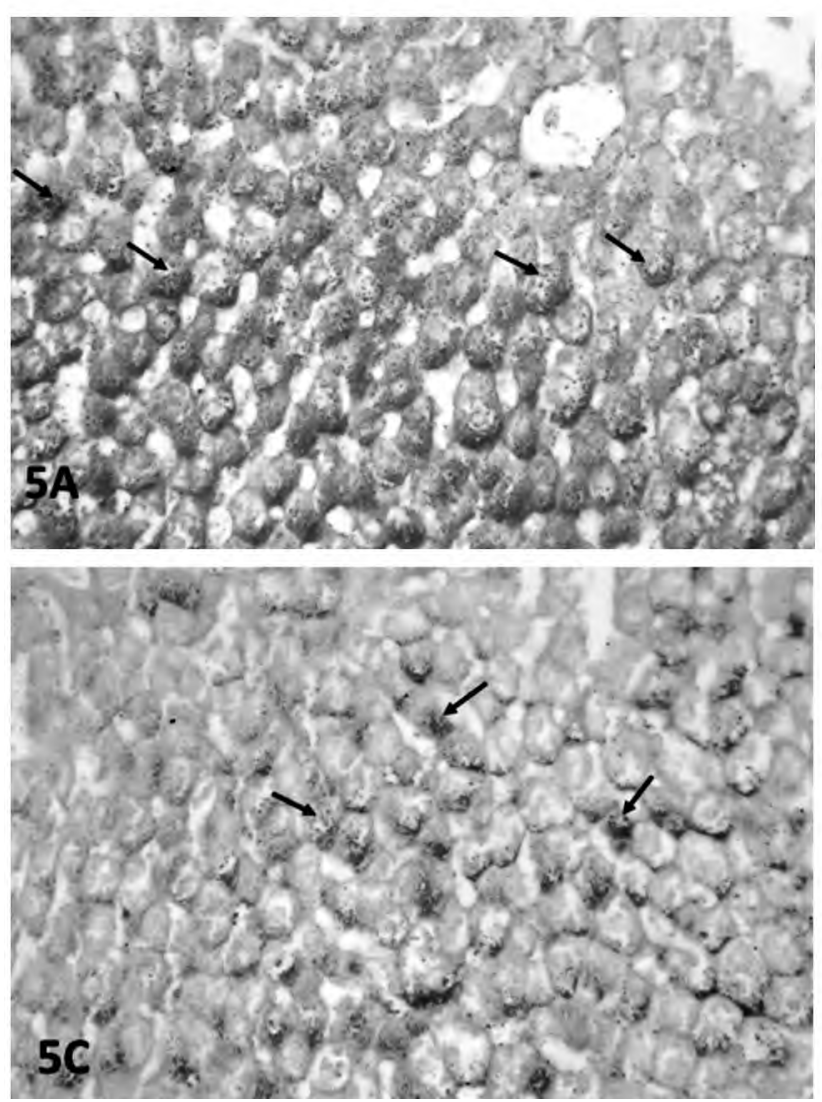

Results of the kidney:

Examination of $\mathrm{H} \& \mathrm{E}$ stained kidney sections of rats of the control group revealed that the parenchyma of the renal cortex was formed of renal corpuscles, the Proximal Convoluted Tubules (PCTs), the Distal Convoluted Tubules (DCTs)

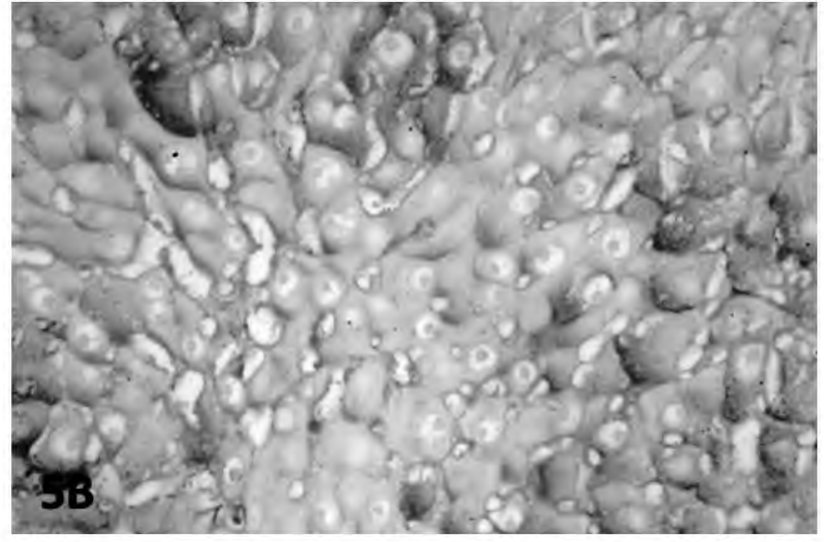

Fig. (5): (A) Showing PAS positive granules in the cytoplasm of the hepatocytes $(\uparrow)$. Group I. PAS X400. (B) Showing apparent decrease of PAS positive granules in most of hepatocytes. Group II. PAS X400. (C) Showing PAS positive granules in the cytoplasm of most the hepatocytes. Group III. PAS X400.

and cortical collecting ducts. Renal glomeruli were formed of lobulated tufts of capillaries and were surrounded by Bowman's capsule. The parietal layer of Bowman's capsule was lined by a single layer of simple squamous epithelium. Between the visceral and parietal layers of Bowman's capsule, 
a patent urinary (filtration) space was seen. The PCTs were seen forming the main bulk of the renal cortex. They had narrow lumina and lined by pyramidal cells with indistinct boundaries and apical brush border. These cells appeared with acidophilic granular cytoplasm and basal rounded vesicular nuclei. The DCTs appeared less numerous in the renal cortex. They had wider lumina and were lined by low cubical cells with pale acidophilic cytoplasm and rounded nuclei Fig. (6A).

$\mathrm{H} \& \mathrm{E}$ stained sections of TAA treated rats (group II) showed congestion of the glomerular capillaries as well as the peritubular capillaries. Most renal tubules were seen with wide lumina and vacuolated cells. Other tubules showed disruption of epithelial lining and intra-luminal debris. Some cells of the renal tubules were seen with deeply stained nuclei. Karyorrhexis could be seen in some cells. Hyaline cast were also noticed inside the lumen of some tubules Fig. (6B).

In group III, an apparent decrease in the congestion of the glomerular and peritubular capillaries was noticed. Few tubules appeared with dilated lumina and vacuolated cells, while most of the renal tubules appeared more or less similar to the control Fig. (6C).

Mallory's trichrome stained sections, of the control group showed minimal amount of blue
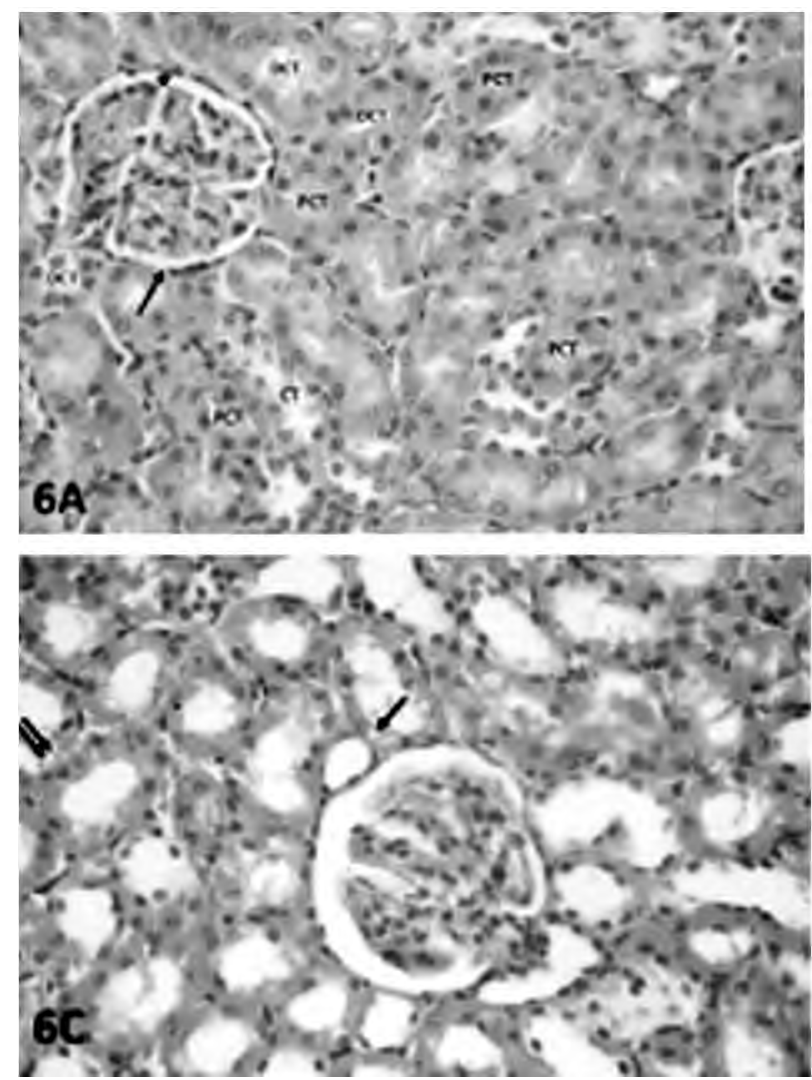

collagen fibers around renal gloemruli and renal tubules Fig. (7A). Significant increase in the amount of collagen fibers $(p<0.05)$ (Table 1$)$ was noticed around renal glomeruli and in-between renal tubules in group II compared to the control group Fig. (7B), while, the amount of collagen fibers was significantly decreased $(p<0.05)$ (Table 1$)$ around renal gloemruli and renal tubules in propolis treated group as compared to TAA group Fig. (7C).

PAS stained sections of the control group showed PAS positive material in renal glomeruli. Most PCTs appeared with preserved brush border and basement membrane Fig. (8A). While in TAA treated group, a significant increase $(p<0.05)$ (Table 1 ) in PAS positive material deposition in the glomerular tuft of most renal glomeruli was noticed, with apparent thickening of the parietal layer of the Bowman's capsule. Partial or complete loss of the brush border of most PCTs with thickening of the basement membrane was also seen Fig. (8B). Group III showed significant decrease $(p<0.05)$ (Table 1) in PAS positive material in the glomerular tuft as compared to group II. Most PCTs appeared with preserved brush border and continuous basement membrane. Apparent decrease in the thickness of the parietal layer of the Bowman's capsule was noticed. Few renal tubules were seen with decreased PAS reaction in the brush border Fig. (8C).

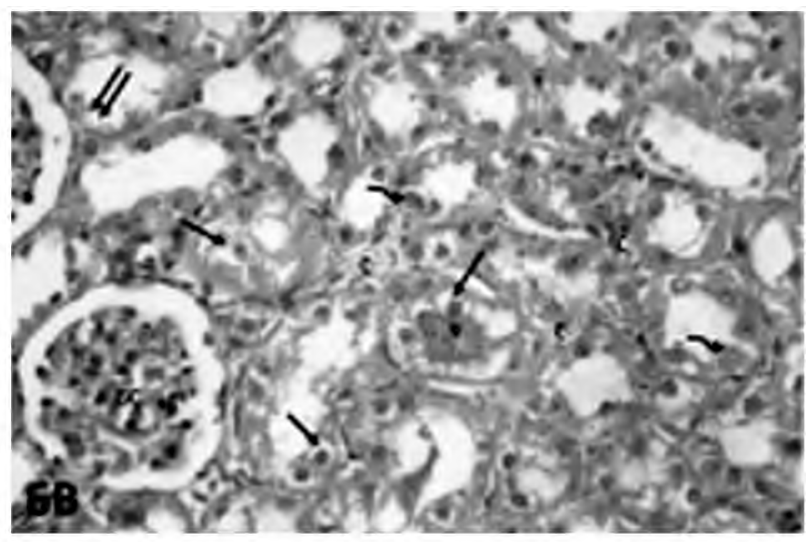

Fig. (6): (A) A photomicrograph of rat kidney section showing renal corpuscles formed of tuft of glomerular capillaries surrounded by Bowman's capsule $(\uparrow)$. Notice the filtration or urinary space $(*)$. The PCTs are seen with narrow lumen and lined with cubical cells with dark acidophilic cytoplasm and rounded vesicular nuclei (PCT). The DCTs have wider lumen and are lined with cubical cells with pale acidophilic cytoplasm (DCT). Collecting tubule are also seen (CT). Group I. H \& E X400. (B) Showing congestion of the glomerular capillaries (GC) and peritubular capillaries (C). Renal tubules are seen with wide lumina and vacuolated cells $(\uparrow)$. Disruption of epithelial lining was seen $(\uparrow \uparrow)$. Notice the karyorrhexis of some nuclei (curved arrow). Some tubules show intraluminal hyaline casts $(\boldsymbol{A})$. Group II. H \& E X400. (C) Showing renal corpuscles with less congested capillaries. Renal tubules are seen with dilated lumina. Loss of tubular cells $(\uparrow \uparrow)$ is seen in some few tubules. Few cells appear vacuolated (१). Group III. H \& E X400. 

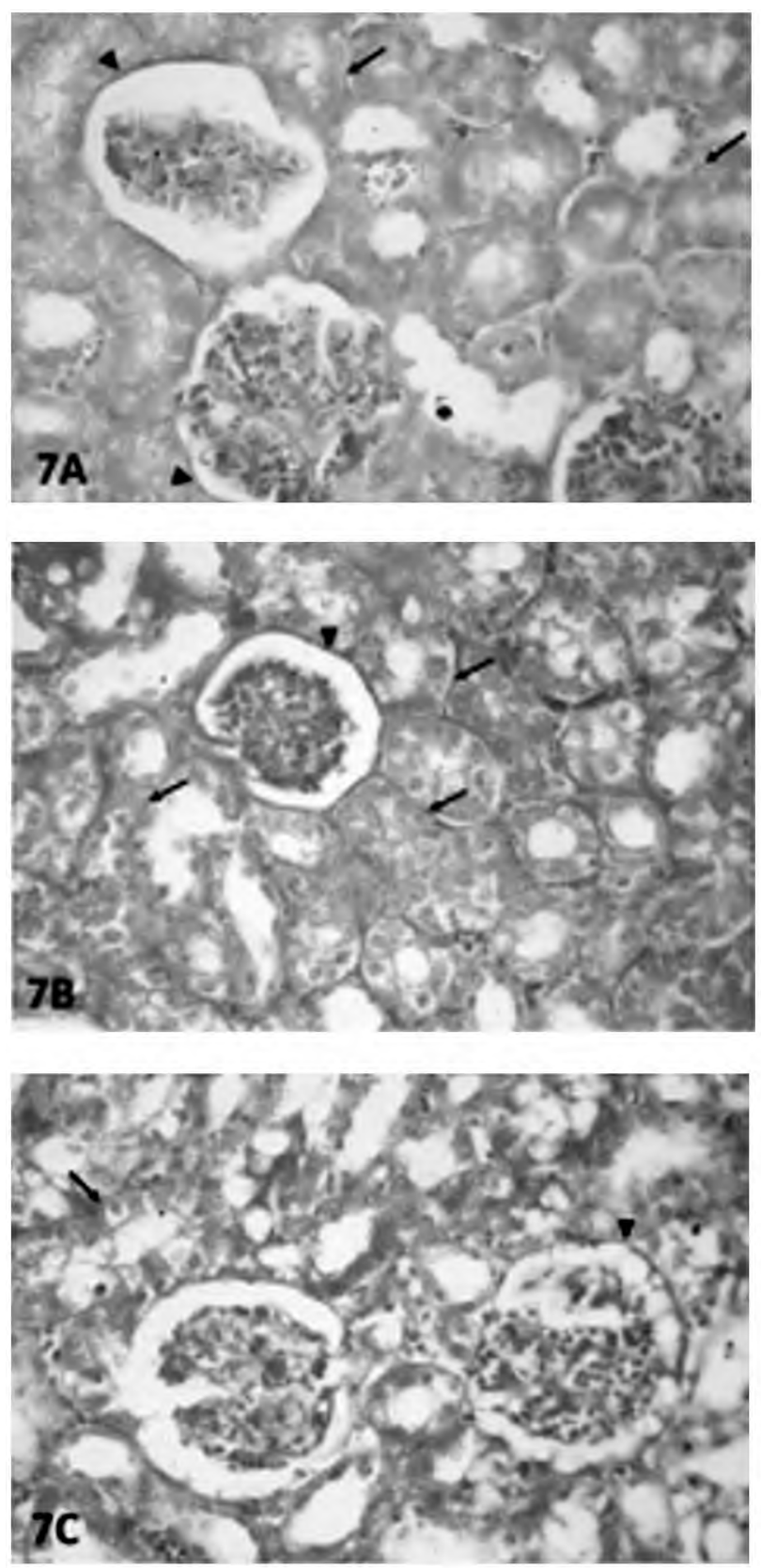

Fig. (7): (A) Showing minimal amount of blue collagen fibers around renal glomeruli $(\boldsymbol{\Delta})$ and renal tubules $(\uparrow)$. Group I. Mallory's trichrome X400. (B) Showing apparent increase in the amount of collagen fibers around the renal glomeruli $(\boldsymbol{A})$ and in-between renal tubules ( $\uparrow$ ). Group II. Mallory's trichrome $X 400$. (C) Showing few collagen fibers around renal glomeruli $(\boldsymbol{A})$ and renal tubules $(\uparrow)$. Group III. Mallory's trichrome X400.
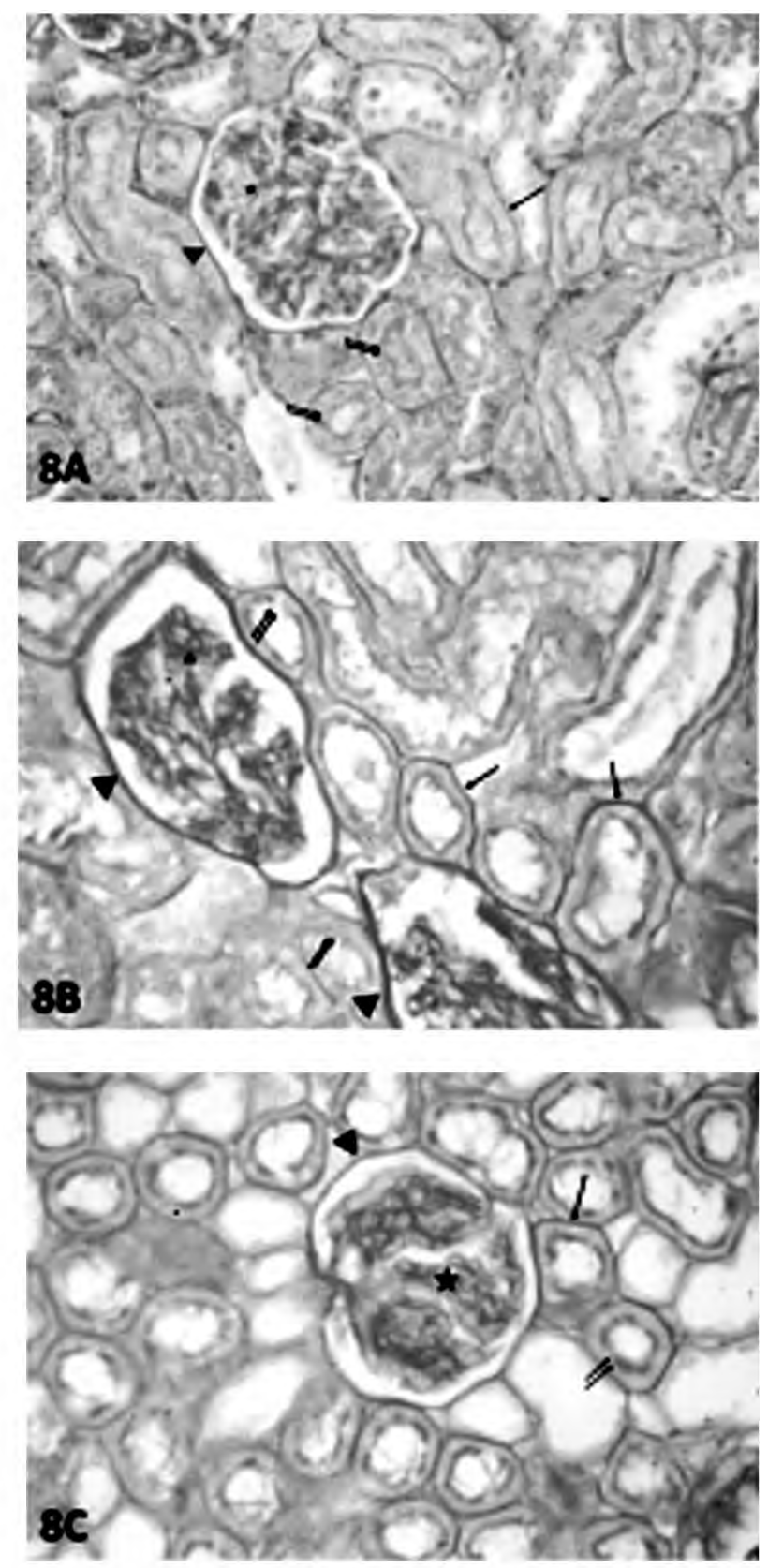

Fig. (8): (A) Showing PAS positive material in renal glomeruli (*) and in parietal layer of the Bowman's capsule $(\Delta)$. Most PCTs are seen with preserved brush border $(\uparrow \uparrow)$ and basement membrane $(\uparrow)$. Group I. PAS X400. (B) Showing apparent thickening of the parietal layer of the Bowman's capsule $(\boldsymbol{\Delta})$ and basement membrane of renal tubules $(\uparrow)$. Partial or complete loss of the brush border of most PCTs $(\uparrow \uparrow)$ is seen. Apparent increase in PAS positive material $(*)$ is also noticed in the glomerular tuft. and thickening of the basement membrane was also noticed. Group II. PAS X400. (C) Showing apparent decrease in the thickness of parietal layer of the Bowman's capsule ( $\boldsymbol{\Delta}$ ) and basement membrane of renal tubules $(\uparrow)$. Notice the preserved brush border $(\uparrow \uparrow)$ in most the PCTs. Group III. PAS X400. 
Morphometric results (Tables 4,5):

\section{Results of the liver (Table 4):}

1 - The mean area percentage of collagen fibers revealed significant increase $(p \leq 0.05)$ in TAA group compared with the control group. Meanwhile, there was a significant decrease $(p \leq 0.05)$ in TAA-propolis treated group compared with TAA group. However, there was significant increase $(p \leq 0.05)$ in TAA-propolis treated group compared with the control group.

2- The mean optical density of glycogen granules showed significant decrease $(p \leq 0.05)$ in TAA group in comparison to the control group. While, there was a significant increase $(p \leq 0.05)$ in TAA-propolis treated group in comparison to TAA group. However, there was significant decrease $(p \leq 0.05)$ in TAA-propolis treated group compared with control group.

Table (4): Mean \pm SD of area $\%$ of collagen fibers and optical density of glycogen in liver sections of different groups.

\begin{tabular}{lcc}
\hline Groups & $\begin{array}{c}\text { Area \% of } \\
\text { collagen fibers }\end{array}$ & $\begin{array}{c}\text { Optical denisty } \\
\text { of glycogen }\end{array}$ \\
\hline Control & $1.53 \pm 1.01$ & $90.97 \pm 4.71$ \\
TAA & $7.48 \pm 1.88 \mathrm{a}$ & $60.80 \pm 1.11 \mathrm{a}$ \\
TAA-Propolis treated & $4.80 \pm 2.00 \mathrm{ab}$ & $81.13 \pm 6.63 \mathrm{ab}$ \\
\hline
\end{tabular}

a: Significance from control group.

b: Significance from TAA group.

\section{Results of the kidney (Table 5):}

1- The mean area percentage of collagen fibers stained by Mallory's trichrome stain was significantly increased $(p \leq 0.05)$ in TAA group as compared to that of the control group. While, there was a significant decrease of mean area percentage of collagen fibers in TAA-propolis treated group as compared to TAA group. However, there was significant increase $(p \leq 0.05)$ in TAA-propolis treated group as compared with control group.

2- The mean optical density of glycogen contents stained by PAS was significantly increased $(p \leq 0.05)$ in TAA group as compared to that of the control group. While, there was a significant decrease in the mean optical density of glycogen contents stained by PAS in TAA-propolis treated group as compared to TAA group. However, there was significant increase $(p \leq 0.05)$ in TAApropolis treated group compared with the control group.
Table (5): Mean \pm SD of area $\%$ of collagen fibers and optical density of glycogen in kidney sections of different groups.

\begin{tabular}{lcc}
\hline Groups & $\begin{array}{c}\text { Area \% of } \\
\text { collagen fibers }\end{array}$ & $\begin{array}{c}\text { Optical denisty } \\
\text { of glycogen }\end{array}$ \\
\hline Control & $3.70 \pm 1.92$ & $68.35 \pm 2.77$ \\
TAA & $16.24 \pm 3.60 \mathrm{a}$ & $80.67 \pm 1.76 \mathbf{a}$ \\
TAA-Propolis treated & $7.42 \pm 2.59 \mathrm{ab}$ & $74.99 \pm 3.84 \mathbf{a b}$ \\
\hline
\end{tabular}

a: Significance from control group.

b: Significance from TAA group.

\section{Discussion}

The $27.27 \%$ mortality rate in TAA treated rat group during the two weeks study period could be explained by the hepatic and renal dysfunction induced by TAA. Absence of mortalities in the propolis treated group denotes prompt amelioration of hepatorenal dysfunction.

The observed reduction in FBW and BW\% in TAA and TAA-propolis treated groups could be a result of direct and/or indirect TAA toxicity as explained by Al-Attar and Al-Rethea [25] who stated that weight loss or inappropriate weight gain with TAA administration could be induced either by the direct effect of TAA on the food intake behavior or increased protein catabolism and hampered utilization of food consumed during the intoxication period with concomitant loss of the animal appetite and subsequent reduction of food ingestion, as well as gastrointestinal toxicity that could reduce absorption of nutrients from the intestine, or due to excessive loss of water, salts and proteins as a result of renal injury with subsequent dehydration and weight loss.

Although the ALW was increased in both TAA treated groups compared to controls, this increase didn't reach statistical significance, however, the RLW and RKW were significantly increased in rats received TAA, this could be explained by the concomitant body weight reduction. Guerra et al., [26] explained the increase of liver weight and volume by the increase in the collagen content, and not a consequence of an increase in the parenchyma tissue, the parenchyma may have suffered a decrease in volume, as the increased serum levels of AST and ALT indicate low hepatic integrity.

This was confirmed by our histopathological results and morphometric analysis that showed significant increase of collagen content in portal tract, around the central vein and in-between hepatocytes. This was discussed by some authors who 
stated that accumulation of collagen following inflammation is caused by production of cytokines by both activated Kupffer cells and circulating immune cells. These cytokines activate the quiescent stellate cells in the space of Disse to transdifferentiate to myofibroblast-like cells that secrete collagen. They added that collagen and other extracellular matrix molecules are accumulated faster than their degradation by metalloproteases released from macrophages. With progression of injury, fibrosis occurs around portal tracts or central veins [27].

Our study confirms that TAA induces hepatic injury as proved by the elevated ALT (3.2 times controls) and AST (2.8 times controls). This is in accordance with Abul et al., [28] who stated that hepatocyte necrosis and inflammation induced by TAA result in significant increase in serum ALT activity, as ALT leaks from the cytoplasm of the hepatocytes into the blood. Moreover, Reddy et al., [29] reported that TAA eventually lead to significant impairment of hepatic tissue integrity, excretory and synthetic functions, as well as hepatic oxidative stress.

This was confirmed in our study by the examination of $\mathrm{H} \& \mathrm{E}$ stained liver sections that revealed distortion of liver architecture. Hepatocytes appeared with vacuolated cytoplasm and small dark peripheral nuclei, increase in the nuclear size with prominent multiple nuclei with massive mononuclear cellular infiltration in group II (TAA group). This was in accordance with Hajovsky et al., [7] Also, proliferation of bile duct was evident, this was in agreement with Kadir et al., [2] who stated that TAA induced bile duct proliferation (ductular reaction), hepatic necrosis, liver cirrhosis and hepatocellular carcinoma.

Ductular Reaction (DR) is associated with transdifferentiation of liver cells and plays an important role in hepatic regeneration. The origin of active cells during DR can be cholangiocytes, hepatocytes, or hepatic progenitor cells [30].

The renal impairment observed in this study indicated by the significantly elevated urea (1.7 times controls), creatinine (5.8 times controls), KIM-1 (almost 2 times control) as well as reduced potassium ( 0.8 times controls) is in accordance to Edward and Baker [31] who stated that TAA is selectively toxic to hepatocytes, renal proximal convoluted tubular cells and cortical thymocytes. In addition, Cengiz [32] demonstrated that renal dysfunction could be a consequence of end-stage hepatic damage. TAA induced injury to the proxi- mal renal tubule, where potassium is reabsorbed, could explain the observed hypokalemia.

This was further confirmed by the histopathological study that revealed that administration of TAA to rats led to disruption of epithelial lining of the renal tubules with appearance of intraluminal debris and hyaline cast. Some cells of the renal tubules were seen vacuolated with deeply stained nuclei with karyorrhexis of some nuclei. The intraluminal acidophilic hyaline casts noticed could be due to combination of the sloughed tubular cells with Tamm-Horsfall protein present in the lumen of the tubules. In addition, impairment of sodium reabsorption by the damaged tubular cells led to increase in its concentration in the lumen which resulted in polymerization of Tamm-Horsfall protein forming a gel-like material thus contributing in cast formation [33].

TAA induced toxicity and organ dysfunction could be attributed to the generation of Reactive Oxygen Species (ROS) [34], secondary to its metabolism into TAA-S-dioxide, which binds to cellular macromolecules leading to change in cell permeability and calcium uptake. This interruption of calcium stores inhibits mitochondrial activity [7]. A number of previous studies proved the occurrence of oxidative stress in hepatic tissues following TAA administration [35,36] .

In this work, oxidative stress was proved in renal tissue by elevated MDA and GST. This is in accordance with a study by Etoh et al., [37] who stated that Nicotinamide Adenine Dinucleotide Phosphate (NADPH) oxidase, as a major source of ROS production in the kidney, has been strongly implicated in the development of renal oxidative damage. It was reported that peroxidation of lipids is evident in the renal brush border [38,39] and it also changes the properties of biological membranes, resulting in severe cell damage [40] and lyses [41].

The observed elevation in GST, after 2 weeks study period, is because during oxidative stress, the body uses its defense mechanism to minimize the process of lipid peroxidation using these antioxidant enzymes, thus, the activity of these enzymes becomes higher in early stages of TAA induced oxidative damage. When the oxidative insult was continued for a long period, the enzymes become depleted and unable to fight against the free radicals, suggesting advanced stages of TAA induced peroxidation [42]. Nebert and Vasiliou [43] stated that GST genes are upregulated in response to oxidative stress. The GST is highly inducible both 
at the mRNA and protein level to protect against hydrogen peroxide and 4-hydroxynonenal (HNE)induced cytotoxicity [44]. GST is released into the urine during renal injury, which makes it very early indicators of tubular damage [45]

MPO activity as a neutrophil-specific marker of immune system activation was assessed in this work and was significantly elevated indicating inflammatory response to TAA intoxication. This associated inflammation is explained by Amer et al., [46] who demonstrated an elevation of inflammatory cytokines; Interleukin (IL)-6, IL-1B and Tumor Necrosis Factor (TNF)- a in blood samples of TAA-treated group. Vokalova et al., [3] have shown that liver and kidney injury induced by TAA is associated with the release of DNA which stimulates innate immunity and induces sterile inflammation, exacerbating tissue damage. A study on liver by Selders et al., [47] demonstrated that TAA administration led to degenerative changes such as necrosis and neutrophilic infiltrates. Damaged hepatocytes were replaced by aggregates containing a mixture of macrophages and neutrophils, whose presence can lead to chronic inflammation and fibrosis.

Beside the oxidative stress, inflammatory and apoptotic markers, there are many molecular markers used to assess the kidney injury including the Kidney Injury Molecule-1 (KIM-1) [48,49] . In this study KIM-1 showed a significant positive correlation with both urea and creatinine. Ichimura et al., [50] reported that KIM-1 is a specific and sensitive novel biomarker of renal proximal tubular injury, moreover, it outperforms serum urea and creatinine as predictors of histopathological changes in the PCT in response to many toxins or pathological conditions [51]. Wu et al., [52] demonstrated that mRNA levels associated with this protein have been shown to increase more than any other gene after kidney injury. In this study, renal tissue KIM1 was significantly elevated in rats exposed to TAA when compared with controls (almost 2 times controls) indicating renal tissue damage, that could be explained by the observed oxidative stress and inflammatory response, confirmed by the significant positive correlation between both MDA, GST and MPO with KIM-1. Furthermore, Prozialeck et al., [53] \& Bolignano et al., [54] stated that the ectodomain of KIM-1 has been shown to be cleaved from cells both in vitro and in vivo and deposited within the urine of rodents after proximal tubular injury, which suggests the use of urinary KIM-1 as a nephrotoxicity biomarker as well as predictors of the outcome.
Renal damage was confirmed by the histopathological result that showed a significant increase in the mean area percentage of collagen fiber deposition as demonstrated by Mallory's trichrome stain and the significant increase of PAS positive material in the renal glomeruli in TAA group. This was explained by some researchers who reported that mesangial cells transformate into myofibroblasts that produce large amounts of collagen (type I and type IV) and glycoproteins [55]. Also, renal tubular epithelial cells can be converted into myofibroblasts through Epithelial-Mesenchymal Transition (EMT) after their stimulation with physical or chemical factors, or cytokines. Necrosis and apoptosis of tubular cells led to aggregation of macrophage which played an essential role in renal interstitial fibrosis. Macrophages produce tumor necrosis factor a (TNF- $(\mathrm{x})$ and transforming growth factor 0 (TGF- 0 ) that induce the transformation of tubular cells [56]

Moreover, examination of PAS stained sections of TAA group in the current study revealed apparent thickening of basement membranes of some tubules as well as of the parietal layer of Bowman's capsule. This was I agreement with some authors who stated that this might be due to up-regulation of integrins, laminin and fibronectin with subsequent increase in basement membrane thickness [57]. In addition, there was loss of the brush border of the PCTs, this was also reported by [58] who detected loss of the brush border, cell polarity, and adhesion between cells and the basement membrane and they explained these findings by the fact that necrosis and apoptosis can all lead to the detachment of tubular cells from the basement membrane, leaving behind areas of denuded basement membrane.

In our results propolis did not produce any change in the measured anthropometric parameters when compared with TAA group. Both liver and kidney functions were improved as indicated by significant reduction in ALT (only 1.7 times controls vs. 3.2 in TAA group), AST (only 1.7 times controls vs. 2.8 in TAA group), urea (1.1 times controls vs. 1.7 in TAA group), creatinine (only 3.1 times controls vs. 5.8 in TAA group), and KIM-1 expression (1.3 times controls vs. 2 times in TAA), with concomitant elevation in potassium level ( 0.9 times control vs. 0.8 in TAA) when compared to TAA group, however the levels were still significant from controls, these results indicate a partial hepatoprotective and renoprotective role of propolis within the 2 weeks study period. These findings are in agreement with El-Mahalaway et al., [59]. Moreover, the reduction in KIM-1 and caspase-3 immunoreaction was observed in a study 
carried by Aldahmash et al., [18] when propolis was administered in gentamicin induced renal toxicity. Histologically, in the current work, propolis partially attenuated the destructive effect of TAA on the structure of both liver and kidney tissues.

This protective effect of propolis could be explained by its antioxidant properties proved by reduction in MDA and GST as well as its antiinflammatory effect explained by reduced MPO level. This is in agreement with Guimarães et al., [60] who reported that propolis could exhibit its protective effects by protecting mitochondria against oxidative damage. This protection may be attributed to its ability to inhibit lipid peroxidation. Propolis contains a group of antioxidants including flavonoids, phenolic acid esters, terpenes, cinnamic acid and others exhibit capability of combating against lipid peroxidation that can impair cellular structure and functions due to its free radicals scavenging effect [61]. This crude can also activate catalase and superoxide dismutase that have capability against free radicals [62]

Furthermore, Farooqui and Farooqui [63] reported that propolis has in vitro and in vivo antiinflammatory and immunomodulatory actions, these effects could be due to its ability to inhibit neutrophil infiltration, to suppress proinflammatory cytokines as TNF- $\alpha$ and interleukins. It also caused stimulation of macrophages and thus prompting specific and nonspecific immune defense mechanisms [64]. In addition, Song et al., [65] suggested that propolis exerts its anti-inflammatory effect by inhibiting inducible Nitric Oxide Synthase (iNOS) gene expression and activity. The mechanism of iNOS inhibition included the action on the nuclear factor-kappa B sites in the iNOS promoter and hence iNOS gene downregulation, in addition to the direct inhibition of its catalytic activity. Moreover, the hepatoprotective effect of propolis was explained by its potent inhibitory effects on Cytochrome (CYP) 2E1, a CYP450 isoform that plays a major role in the metabolism of endogenous compounds as well as xenobiotics [66]. Likewise, propolis improved the activity of hepatic microsomal metabolizing enzymes [67]

\section{Conclusion:}

In conclusion, the present study suggested that propolis could partially protect against the hepatorenal damage induced by TAA, which might be related to attenuation of oxidative stress and inflammation. In addition, KIM- 1 could be used as a successful biomarker for renal injury.

\section{References}

1- ZALESKA-MEDYNSKA A., GORSKA P., SOBCZAK J.W. and JAN H.: Thioacetamid and thiourea impact on visible light activity of TiO2. Applied Catal. B Environ., 76 (1): 1-8, 2007.

2- KADIR F.A., OTHMAN F., ABDULLA M.A., HUSSAN F. and HASSANDARVISH P.: Effect of Tinospora crispa on thioacetamide-induced liver cirrhosis in rats. Indian J. Pharmacol., 43 (1): 64-8, 2011.

3- VOKÁlOVÁ L., LAUKOVÁ L., CONKA J., MELISKOVÁ V., BORBÉLYOVÁ V., BÁBÍ_KOVÁ J., TÓTHOVÁ L., HODOSY J., VLKOVÁ B. and CELEC P.: Deoxyribonuclease partially ameliorates thioacetamideinduced hepatorenal injury. Am. J. Physiol. Gastrointest. Liver Physiol., 312: G457-G463, 2017.

4- ICHIMURA R., MIZUKAMI S., TAKAHASHI M., TANIAI E., KEMMOCHI S., MITSUMORI K. and SHIBUTANI M.: Disruption of Smad-dependent signaling for growth of GST-P-positive lesions from the early stage in a rat two-stage hepatocarcinogenesis model. Toxicology and Applied Pharmacology, 246: 128-40, 2010.

5- MARQUES P.E., OLIVEIRA A.G., PEREIRA R.V., DAVID B.A., GOMIDES L.F., SARAIVA A.M., PIRES D.A., NOVAES J.T., PATRICIO D.O., CISALPINO D., MENEZES-GARCIA Z., LEEVY W.M., CHAPMAN S.E., MAHECHA G., MARQUES R.E., GUABIRABA R., MARTINS V.P., SOUZA D.G., MANSUR D.S., TEIXEIRA M.M., LEITE M.F. and MENEZES G.B.: Hepatic DNA deposition drives drug-induced liver injury and inflammation in mice. Hepatology, 61: 348-60, 2015.

6- AL-ATTAR A.M., ALROBAI A.A. and ALMALKI D.A.: Protective effect of olive and juniper leaves extracts on nephrotoxicity induced by thioacetamide in male mice. Saudi Journal of Biological Sciences, 24 (1): 15-22, 2017.

7- HAJOVSKY H., HU G., KOEN Y., SARMA D., CUI W., MOORE D.S., STAUDINGER J.L. and HANZLIK R.P.: Metabolism and toxicity of thioacetamide and thioacetamide S-oxide in rat hepatocytes. Chem. Res. Toxicol., 25 (9): 1955-63, 2012.

8- STEHBENS W.E.: Oxidative stress, toxic hepatitis and antioxidants with particular emphasis on zinc. Exp. Mol. Pathol., 75 (3): 265-76, 2003.

9- OZBEK E.: Induction of Oxidative Stress in Kidney. Int. J. Nephrol., 2012: 1-9, 2012.

10- BURDOCK G.A.: Review of the biological properties and toxicityof bee propolis (propolis). Food Chem. Toxicol., 36: 347-63, 1998.

11- CHEN C., WENG M., WU C. and LIN J.: Comparison of radicalscavenging activity, cytotoxic effects and apoptosis inductionin human melanoma cells by Taiwanese propolis fromdifferent sources. Evid. Based Complement Alternat. Med., 1: 175-85, 2004.

12- NASSAR S., MOHAMED A., SOUFY H., NASR S. and MAHRAN K.: Immunostimulant effect of Egyptian propolis in rabbits. Sci. World J., 2012: 901516, 2012.

13- CAMPOS J.F., DOS SANTOS U.P., Da ROCHA PDOS S., DAMIAO M.J., BALESTIERI J.B., CARDOSO C.A., PAREDES-GAMERO E.J., ESTEVINHO L.M., De PICOLI SOUZA K. and Dos SANTOS E.L.: Antimicrobial, antioxidant, anti-inflammatory and cytotoxic activities 
of propolis from the stingless bee Tetragonisca fiebrigi (Jatai). Evidence-Based Complementary Altern. Med., 2015: 296186, 2015.

14- EL-KOTT A. and OWAYSS A: Protective effects of propolis against theamitraz hepatotoxicity in mice. $\mathbf{J}$. Pharmacol. Toxicol., 3: 402-8, 2008.

15- PERRON N. and BRUMAGHIM J.: A review of the antioxidant mechanisms of polyphenol compounds related to iron binding. Cell Biochem. Biophys., 53: 75-100, 2009.

16- SHAO X., TIAN L., XU W., ZHANG Z., WANG C., QI C., NI Z. and MOU S.: Diagnostic Value of Urinary Kidney Injury Molecule 1 for Acute Kidney Injury: A Meta-Analysis. PLoS ONE, 9 (1): e84131, 2014.

17- MURAD H.A.S., RAFEEQ M.M. and MALATANI N.N.: Effects of Candesartan and Losartan on Thioacetamide Induced Low Grade Renal Dysfunction in Rats. International Journal of Pharmacology, 14: 1046-50, 2018.

18- ALDAHMASH B.A., EL-NAGAR D.M. and IBRAHIM K.E.: Reno-protective effects of propolis on gentamicininduced acute renal toxicity in swiss albino mice. Nefrologia, 36 (6): 643-52, 2016.

19- TIETZ N.W.: Fundamentals of clinical chemistry, W.B. Saunders Co., Philadelphia, 1976.

20- VAS SAULT A., GRAFMEYER D., NAUDUN C., et al.: Protocol de validation de techniques. Commission "Validation de techniques". Document B, stade. Ann. Biol. Clin., 44: 686-745, 1986.

21- YOUNG D.S., THOMAS D.W., FRIEDMAN R.B. and PESTANER L.C.: Effects of drugs on clinical laboratory tests. Clin. Chem., 18 (10): 1041-303, 1975.

22- OHKAWA H., OHISHI W. and YAGI K.: Assay for lipid peroxides in animal tissues by thiobarbituric acid reaction. Anal. Biochem., 95 (2): 351-8, 1979.

23- HABIG W.H., PABST M.J. and JAKOBY W.B.: Glutathione S-transferases. The first enzymatic step in mercapturic acid formation. J. Biol. Chem., 25; 249 (22): 7130-9, 1974.

24- BANCROFT J.D., LAYTON C. and SUVARNA S.K.: Bancroft's Theory and Practice of Histological Techniques. 7th ed. Elsevier Churchill Livingstone: London, United Kingdom. pp. 386-535, 2013.

25- AL-ATTAR A.M. and AL-RETHEA H.A.: Chemoprotective effect of omega-3 fatty acids on thioacetamide induced hepatic fibrosis in male rats. Saudi J. Biol. Sci., 24 (4): 956-65, 2017.

26- GUERRA R.R., TROTTA M.R., ALOIA T.P.A., DAGLI M.L.Z. and HERNANDEZ-BLAZQUEZ F.J.: A novel chronic cirrhosis TAA-induced model in rats. Braz. J. Vet. Pathol., 3 (1): 9-16, 2010.

27- TRABER P.G.1, CHOU H., ZOMER E., HONG F., KLYOSOV A., FIEL M.I. and FRIEDMAN S.L.: Regression of fibrosis and reversal of cirrhosis in rats by galectin inhibitors in thioacetamide-induced liver disease. PLoS One; 9, 8 (10): e75361, 2013.

28- ABUL K., NAJMI K.K. and PILLAI S.N.: Effect of Lornithine L-aspartate against thioacetamide-induced hepatic damage in rats. Indian J. Pharm., 42: 384-7, 2010.
29- REDDY P.V., MURTHY C.R. and REDDANNA P.: Fulminant hepatic failure induced oxidative stress in nonsynaptic mitochondria of cerebral cortex in rats. Neurosci. Lett., 368: 15-20, 2004.

30- SATO K., MARZIONI M., MENG F., FRANCIS H., GLASER S. and ALPINI G.: Ductular Reaction in Liver Diseases: Pathological Mechanisms and Translational Significances. Hepatology, 69 (1): 420-30, 2019.

31- EDWARD A. and BAKER E.A.S.: Nonhepatic Thioacetamide Injury. The morphologic Features of proximal renal tubular injury. Am. J. Pathol., 74 (3): 576-90, 1974.

32- CENGIZ M.Z.: Renoprotective effects of Silybum marianum (L.) Gaertn (Silymarin) on thioacetamide-induced renal injury: Biochemical and histopathological approach. Pak. J. Pharm. Sci., 31 (5): 2137-41, 2018.

33- ABUELO J.G.: Normotensive ischemic acute renal failure. N. Engl. J. Med., 357 (8): 797-805, 2007.

34- WANG M.E., CHEN Y.C., CHEN I.S., HSIEH S.C., CHEN S.S. and CHIU C.H.: Curcumin protects against thioacetamide-induced hepatic fibrosis by attenuating the inflammatory response and inducing apoptosis of damaged hepatocytes. J. Nutr. Biochem., 23: 1352-66, 2012.

35- AHMED R.G.: The physiological and biochemical effects on the balance between oxidative stress and antioxidant defense system. Med. J. Islamic World Acad. Sci., 15: 31-42, 2002.

36- SANZ N., DIEZ-FERNANDEZ C., ANDRES D. and CASCALES M.: Hepatotoxicity and aging: Endogenous antioxidant systems in hepatocytes from 2-, 6-, 12-, 18and 30-month-old rats following a necrogenic dose of thioacetamide. Exp. Toxico. Patho., 64: 287-93, 2002.

37- ETOH T., INOGUCHI T., KAKIMOTO M., SONODA N., KOBAYASHI K., KURODA J., SUMIMOTO H. and NAWATA H.: Increased expression of NAD (P) H oxidase subunits, NOX4 and p22phox, in the kidney of streptozotocin-induced diabetic rats and its reversibity by interventive insulin treatment. Diabetologia, 46 (10): 1428-37, 2003.

38- HAMED M.A., ALI S.A. and EL-RIGAL N.S.: Therapeutic potential of ginger against renal injury induced by carbon tetrachloride in rats. Scientific World Journal, 2012: 840421, 2012.

39- AL-YAHYA M., MOTHANA R., AL-SAID M., ALDOSARI M., AL-MUSAYEIB N., AL-SOHAIBANI M., PARVEZ M.K. and RAFATULLAH S.: Attenuation of CCl4-Induced Oxidative Stress and Hepatonephrotoxicity by Saudi Sidr Honey in Rats. Evid. Based Complement. Alternat. Med., 2013: 569037, 2013.

40- ADEWOLE S.O., SALKO A.A., DOHERTY O.W. and NAICKER T.: Effect of Melatonin on Carbon Tetrachloride-Induced Kidney Injury in Wistar Rats. African Journal of Biomedical Research, 10: 153-64, 2007.

41- HESAMI Z., JAMSHIDZADEH A., AYATOLLAHI M., GERAMIZADEH B., FARSHAD O. and VAHDATI A. Effect of Platelet-Rich Plasma on CCl4- Induced Chronic Liver Injury in Male Rats. Int. J. Hepatol., 2014: 932930, 2014.

42- KADIR F.A., KASSIM N.M., ABDULLA M.A. and YEHYE W.A.: Effect of oral administration of ethanolic extract of Vitex negundo on thioacetamide-induced neph- 
rotoxicity in rats. BMC Complementary and Alternative Medicine, 13: 294, 2013.

43- NEBERT D.W. and VASILIOU V.: Analysis of the glutathione S-transferase (GST) gene family. Hum. Genomics, 1 (6): 460-4, 2004

44- ZHU H., ZHANG L., AMIN A.R. and LI Y.: Coordinated upregulation of a series of endogenous antioxidants and phase 2 enzymes as a novel strategy for protecting renal tubular cells from oxidative and electrophilic stress. Exp. Biol. Med., 233: 753-65, 2008.

45- SUNDBERG A., APPELKVIST E.L., DALLNER G. and NILSSON R.: Glutathione transferases in the urine: sensitive methods for detection of kidney damage induced by nephrotoxic agents in humans. Environ. Health Perspect., 102: 293-6, 1994.

46- AMER M.G., MAZEN N.F. and MOHAMED A.M.: Caffeine intake decreases oxidative stress and inflammatory biomarkers in experimental liver diseases induced by thioacetamide: Biochemical and histological study. International Journal of Immunopathology and Pharmacology, 30 (1): 13-24, 2017.

47- SELDERS G.S., FETZ A.E., RADIC M.Z. and BOWLIN G.L.: An overview of the role of neutrophils in innate immunity, inflammation and host-biomaterial integration. Regen. Biomater., 4 (1): 55-68, 2017.

48- HAVASI A. and BORKAN S.: Apoptosis and acute kidney injury. Kidney Int., 80 (1): 29-40, 2011.

49- ENDRE Z., PICKERING J., WALKER R., DEVARAJAN P., EDELSTEIN C., BONVENTRE J., FRAMPTON C.M., BENNETT M.R., MA Q., SABBISETTI V.S., VAIDYA V.S., WALCHER A.M., SHAW G.M., HENDERSON S.J., NEJAT M., SCHOLLUM J.B. and GEORGE P.M.: Improved performance of urinary biomarkers of acute kidney injury in the critically ill by stratification for injury duration and baseline renal function. Kidney Int., 79: 1119-30, 2012.

50- ICHIMURA T., HUNG C.C., YANG S.A., STEVENS J.L. and BONVENTRE J.V.: Kidney injury molecule-1: A tissue and urinary biomarker for nephrotoxicant-induced renal injury. Am. J. Physiol. Renal Physiol., 286: 552-63, 2004.

51- BONVENTRE J.V.: Kidney Injury Molecule-1 (KIM-1): A specific and sensitive biomarker of kidney injury. Scand. J. Clin. Lab. Invest. Suppl., 241: 78-83, 2008.

52- WU J., XIONGXIONG PAN X., FU H., ZHENG Y., DAI Y., YIN Y., CHEN Q., HAO Q., BAO D. and HOU D.: Effect of curcumin on glycerol-induced acute kidney injury in rats. Sci. Rep., 7: 10114, 2017.

53- PROZIALECK W.C., VAIDYA V.S., LIU J., WAALKES M.P., EDWARDS J.R., LAMAR P.C., BERNARD A.M., DUMONT X. and BONVENTRE J.V.: Kidney injury molecule-1 is an earlybiomarker of cadmium nephrotoxicity. Kidney Int., 72: 985-93, 2007.

54- BOLIGNANO D., LACQUANITI A., COPPOLINO G., DONATO V., CAMPO S., FAZIO M.R., NICOCIA G. and BUEMI M.: Neutrophil gelatinase-associated lipocalin (NGAL) and progression of chronic kidney disease. Clin. J. Am. Soc. Nephrol., 4: 337-44, 2009.

55- FU R.G., ZHANG T., WANG L., DU Y., JIA L.N., HOU J.J., YAO G.L., LIU X.D., ZHANG L., CHEN L., GUI
B.S. and XUE R.L.: Inhibition of the $\mathrm{K}^{+}$channel $\mathrm{K}(\mathrm{Ca})$ 3.1 reduces TGF- $\beta$ 1-induced premature senescence, myofibroblast phenotype transition and proliferation of mesangial cells. PLoS One, 9 (1): e87410, 2014.

56- LUO L., SUN Z., WU W. and LUO G.: Mycophenolate mofetil and FK506 have different effects on kidney allograft fibrosis in rats that underwent chronic allograft nephropathy. BMC Nephrol., 13: 53, 2012.

57- GHALY E.N., GERGIS S.W., AZIZ J.N., YASSA H.D. and HASSAN H.A.: Role of mesenchymal stem cell therapy in cisplatin induced nephrotoxicity in adult albino rats: Ultrastructural and biochemical study. Acta Medica International, 32 (1): 57-66, 2014.

58- EZZ-DIN D., GABRY M.S., FARRAG A.R. and ABDELMONEIM A.E.: Physiological and histological impact of Azadirachta indica (neem) leaves extract in a rat model of cisplatin-induced hepato and nephrotoxicity. J. Med. Plants. Res., 5 (23): 5499-506, 2011.

59- EL-MAHALAWAY A.M., SELIM A.A. and MAHBOUB F.A.R.: The potential protective effect of propolis on experimentally induced hepatitis in adult male albino rats. Histological and immunohistochemical study. J. Histol. Histopathol., 2: 14, 2015.

60- GUIMARÃES N.S.S., MELLO J.C., PAIVA J.S., BUENO P.C.P., BERRETTA A.A., TORQUATO R.J., NANTES I.L. and RODRIGUE T.: Baccharis dracunculifolia, the main source of green propolis, exhibits potentantioxidant activity and prevents oxidative mitochondrial damage. Food and Chemical Toxicology, 50 (3-4): 1091-7, 2012.

61- BERGAMINI C.M., GAMBETTI S., DONDI A. and CERVELLATI C.: Oxygen, reactive oxygen species and tissue damage. Curr. Pharm. Des., 10 (14): 1611-26, 2004.

62- NEWAIRY A.A. and ABDOU H.M.: Effect of propolis consumption on hepatotoxicity and brain damage in male rats exposed to chlorpyrifos. Afr. J. Biotechnol., 12 (33): 5232-43, 2013.

63- FAROOQUI T. and FAROOQUI A.A.: Beneficial effects of propolis on human health and neurological diseases. Front. Biosci., 4: 779-93, 2012.

64- NAKAMURA T., OHTA Y., OHASHI K., IKENO K., WATANABE R., TOKUNAGA $\mathrm{K}$. and HARADA N.: Protective effect of Brazilian propolis against liver damage with cholestasis in rats treated with $\alpha$ naphthylisothiocyanate. Evidence Based Complementary Altern. Med., 2013: 302720, 2013.

65- SONG Y.S., PARK E.H., HUR G.M., RYU Y.S., KIM Y.M. and JIN C.: Ethanol extract of propolis inhibits nitric oxide synthase gene expression and enzyme activity. J. Ethnopharmacol., 80 (2-3): 155-61, 2002.

66- RYU C.S., OH S.J., OH J.M., LEE J.Y., LEE S.Y., CHAE J.W., KWON K.I. and KIM S.K.: Inhibition of cytochrome $\mathrm{P} 450$ by propolis in human liver microsomes. Toxicol. Res., 32 (3): 207-13, 2016.

67- MAHMOUD E.F. and MAHMOUD M.F.: Evaluation of the effect of propolis extract on the tongue mucosa of an induced toxic rabbit by fenitrothion. Life Sci. J., 10: 767$75,2013$. 


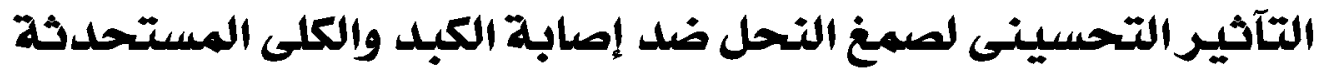

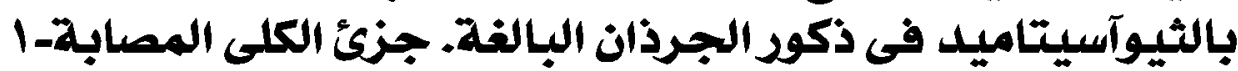

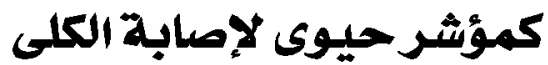

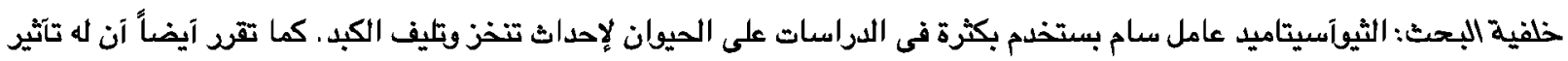
سام على الكلى عن طريق الإجهاد التاكسدى. صمخ النحل معروف آن له خصائص مضادة للاكسدة والإلتهاب. الهدف من العمل : تقييم التآثير الوقائى لصمغ النحل ضد الإند التلف الناتج عن الثيوآسيتاميد فى الكبد والكلى وكذلك تقييم دود جزئ الكلى

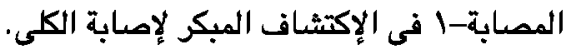

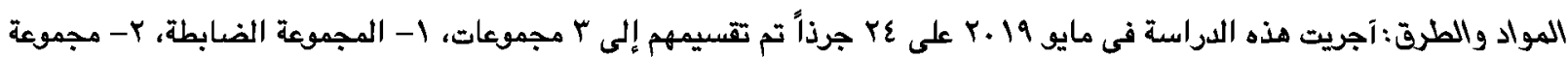

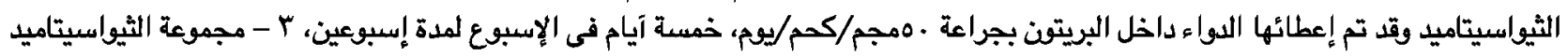

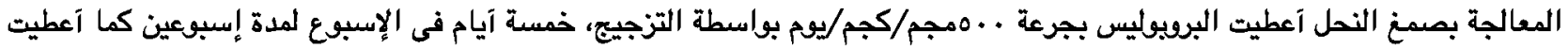

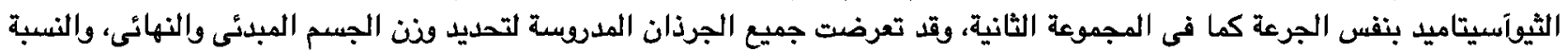

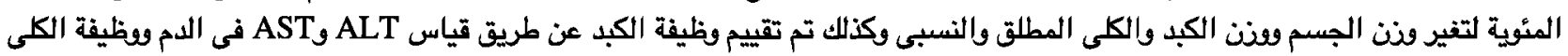

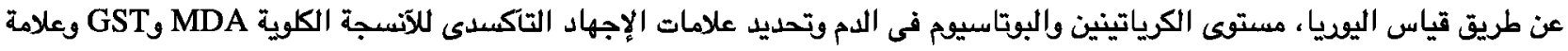

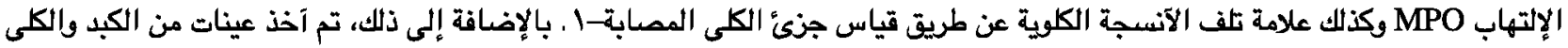
ومعالجتها للدراسات بالميكروسكوب الضونئى

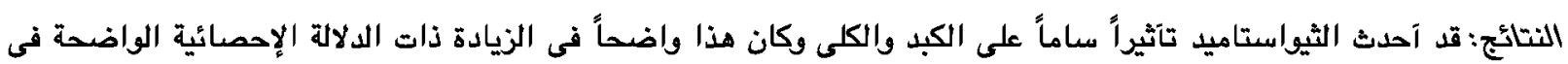

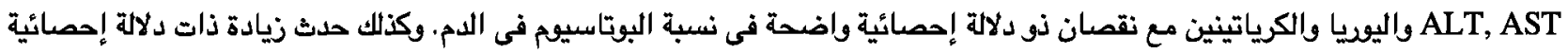

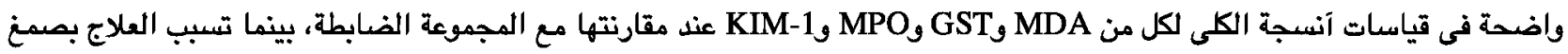

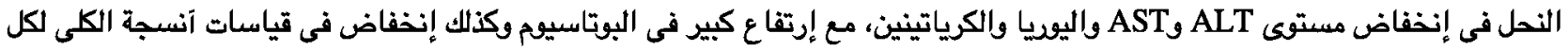

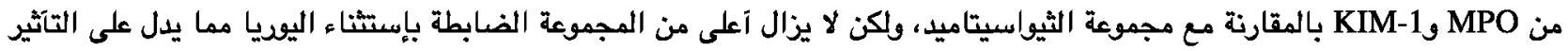

التصسينى الجزئى لصمغ النحل على إصابة الكبد والكلى الناجمة عن الثيواسيتاميد. ولقد تم تاكيد هذه النئ النتائج من خلال النتائج النسيجية.

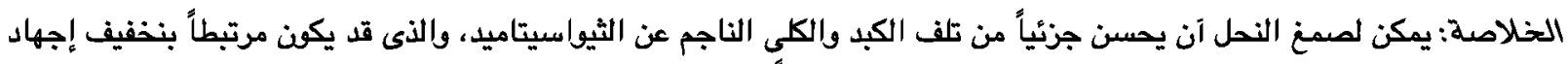

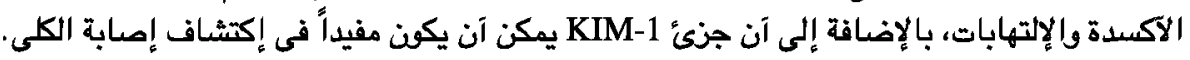

